\title{
Artvin ilinin Şavşat ilçesinde kullanılan hayvan adları üzerine bir deneme
}

\section{Ali Fuat ALTUNTAȘ1}

\begin{abstract}
APA: Altuntaş, A. F. (2019). Artvin ilinin Şavşat ilçesinde kullanılan hayvan adları üzerine bir deneme. RumeliDE Dil ve Edebiyat Araştırmaları Dergisi, (Ö6), 37-52. DOI: 10.29000/rumelide.648412.
\end{abstract}

\section{$\ddot{\mathbf{O} z}$}

İnsanın kendi türünden sonra en yakınında yer alan hayvanlar, kültürlerin oluşmasında ve şekillenmesinde önemli bir yer tutar. Türkiye Türkçesi ağızlarında da hayvan adları, söz varlığı içerisinde önemli yer tutmaktadır. Doğu Grubu ağızları içerinde yer alan Şavşat ağzı da bu bakımdan zenginlik göstermektedir. Şavşat ağzı üzerinde az sayıda çalışma yapılmış olması, çalışmaların dilsel bakımdan eksik olması bu çalışmanın yapılmasına vesile olmuştur. Ancak detaylı bir ağız araştırmasının uzun bir zaman ve emek alması gereği kapsam hayvan adlarıyla sınırlı tutulmuştur. Şavşat ağzı bir bölgenin ağız özelliklerini tam olarak yansıtmamaktadır. Bölgenin, doğudan batıya geçiş noktası üzerinde olması, diğer Türk kavimleriyle bir arada yaşama, savaşlar ve göçler söz varlığında da çeşitliliğe neden olmuştur. Şavşat ağzı incelendiğinde Kıpçak Türkçesinin, Oğuzcanın, Eski Anadolu Türkçesinin özellikleri belirgin olarak görülmektedir. Bu çalışmada hayvan adları referans alınarak bölgeye dikkat çekmek, söz varlığına katkıda bulunmak, ağız araştırmalarının önemini vurgulamak ve kullanılan adlandırmalardaki fonetik özellikleri tespit etmek amaçlanmıştır.

Anahtar kelimeler: Ağız, hayvan adları, Şavşat.

\section{An experiment on animal names used in Şavşat province of Artvin}

\begin{abstract}
The animals that are closest to human beings after their species have an important place in the formation and shaping of cultures. Animal names in Turkey Turkish dialects occupies an important place in the asset. Şavşat dialect, which is located within the Eastern Group dialects, is also rich in this respect. The fact that there were few studies on Şavşat dialect and the lack of linguistic studies led us to do this study. However, a comprehensive oral study takes a long time and effort. Thus, it limited to our study on animal names. Şavşat dialect does not fully reflect the mouth characteristics of a region. The region is located on the transition point from east to west, living together with other Turkish tribes, wars and migrations caused diversity in vocabulary. When Şavşat dialect is examined in detail, the characteristics of Kipchak Turkish, Oguzca and Old Anatolian Turkish are clearly seen. In this study, it was aimed to draw attention to the region, to contribute to vocabulary, to emphasize the importance of oral researches and to identify the phonetic and morphological features of the names used by taking animal names as a reference.
\end{abstract}

Keywords: Dialect, animal names, Şavşat.

1 Arş. Gör., Bandırma Onyedi Eylül Üniversitesi, İnsan ve Toplum Bilimleri Fakültesi, Türk Dili ve Edebiyatı Bölümü (Balıkesir, Türkiye), aaltuntas@bandirma.edu.tr, ORCID ID: 00oo-0002-3063-4835 [Makale kaylt tarihi: 03.10.2019kabul tarihi: 20.11.2019; DOI: 10.29000/rumelide.648412] 


\section{Giriş}

İnsan yüzyllar içerisinde fiziksel ve zihinsel değişimler geçirmiştir. Bugün dünyanın gözünün üzerinde olduğu Şanlıurfa - Göbekli Tepe gibi kalıntılardan elde edilen bulgular biz insanların tarihsel süreç içerisinde nasıl bir gelişim gösterdiğini gözler önüne sermektedir. Tarihin Sıfir Noktası olarak adlandırılan ve dünyanın bilinen en eski kült yapısı olan Göbekli Tepe üzerinde birçok araştırma yapılmakta ve çeşitli teoriler üretilmektedir. Dikkat çekici nokta ise bu yapıdaki çeşitli hayvanlara ait sembollerdir. Anlaşılmaktadır ki insanlar ile hayvanlar arasında tarihsel süreçte bir etkileşim vardır ve hayvanların, bugün kültürümüzün oluşmasında önemli bir etken olduğu göz ardı edilemeyecek bir gerçektir.

İnsanın kendi türünden sonra en yakınında yer alan hayvanlar, kültürlerin oluşmasında ve şekillenmesinde önemli bir yer tutar. Başlangıçta yabani hayvanlardan korunmak için onlarla mücadele eden insan, sonraki dönemlerde hayvanlardan çeşitli yönlerden yararlanma düşüncesi içinde olmuştur. Tavuğun yumurtası, ineğin sütü, boğanın gücü, eşeğin dayanıklılı̆̆ı tanındıkça onlarla daha iyi ilişkiler içerisine girilmiş ve hayvanlardan en üst seviyede faydalanma yoluna gidilmiştir ( Uçar,2013:s.1 ). Hayvanlarla iyi ilişkiler içerisine girmek, hayvanlardan en üst seviyede faydalanmak, farklı kültürlerle etkileşime girmek ve dilin canlı bir varlık olması geçmişte kullanılan adlandırmalarda da hâliyle değişikliğe neden olmuştur. İște bu semboller, simgeler ve adlandırmalar günümüzde bölgeden bölgeye hatta çok kısa mesafelerde bile değişiklik göstermektedir. Tarih boyunca çeşitli devletlere ve milletlere ev sahipliği yapan Artvin ili Şavşat ilçesinde ve bağlı köylerde hayvan adlarının farklılık göstermesi de bu ve buna benzer nedenlerden olmuştur. Her yörenin kendine özgü yemek, türkü, giyim gibi kültürleri vardır. Aynı şekilde kendine has konuşma tarzı da vardır. Buna da Türkiye Türkçesinde genellikle $a \breve{g ̆ z}$ denmektedir. Anadolu'da bugün birbirinden farklı ağızların bulunması, 11. yüzyıldan itibaren bu topraklara yerleşen Oğuz boylarının farklı ă̆ız özelliklerine sahip olmasından kaynaklanmaktadır. Anadolu'ya çeşitli zamanlarda ve çeşitli vesilelerle gelen Oğuz dışı Türk unsurlarla yabancı unsurların da bu ağızların oluşumunda önemli katkıları olmuştur ( Karahan, 2011:s.1 ). Ancak ağız konusunun sınırlarının tam olarak çizilmediği, üzerinde tartışılmaya devam edildiği görülmektedir. Çalışlan konunun kapsamı gereği bu tartışmalara değinilmemiştir. Ancak Şavşat ilçesinin, konuyu daha iyi anlayabilmek ve aydınlatabilmek adına coğrafi özelliklerine, kültür mozaiğine ve tarihine kısaca bakmanın yerinde olacağını düşünmekteyiz.

Şavşat, Doğu Karadeniz Bölgesi’nde bulunan Artvin iline bağlı bir ilçedir. İlçenin doğusunda Ardahan ili ve bu ile bağlı Hanak ilçesi, kuzeydoğusunda da yine Ardahan iline bağlı Posof ilçesi bulunmaktadır. Şavşat'ın güney ve güneybatısında Ardanuç ilçesi, batısında ise Artvin il merkezi ve Borçka ilçesi bulunmaktadır. Kuzeyden de Gürcistan ile sınırdır. Dağlık ve engebeli arazi üzerine kurulmuş ilçenin dört bir yanı yüksek dağlarla çevrilidir. İlçenin, kuzeydoğusunda kalan bölgeleri Anadolu'ya ve Karadeniz'e bağlayan bir geçiş güzergâhı niteliğinde olması, tarihî göç yolları üzerinde bulunması zaman içerisinde birçok savaşa tanıklık etmesini ve farklı devletlerin egemenliği altında kalmasını da beraberinde getirmiştir. Halk arasında yapılan konuşmalardan, eski toprak diye hitap edilen dede ve ninelerimizden, yapılan derleme çalışmalarından, tezlerden ve en önemlisi tarihî kaynaklardan elde ettiğimiz bilgilere göre bölgede MÖ.900 - 650 yılları arasında Urartular ve Kimmerler yaşamaktaydı. Orta Asya'dan yapılan göçler sonucunda bölgeye sırasıyla Saka ( İskit ) Türkleri, Roma İmparatorluğu ve Sasani Devleti hâkim olmuştur. Yavuz Sultan Selim'in Trabzon sancak beyliği sürecinde Artvin Beylerinin korunma talebi üzerine Osmanlı topraklarına katılmasına rağmen Yavuz Sultan Selim’in bölgeden ayrılması üzerine tekrar sancak haline gelip Gürcistan Devleti’ne katılmıştır. Birinci Dünya Savaşı sırasında Ruslarla çetin bir mücadeleye girilmiş ve Rus hâkimiyetinde geçen döneme halk 
arasında Kara Günler denilmiştir. Yapılan antlaşmalar ve Doğu Cephesi komutanı Kâzım Karabekir Paşa önderliğinde bölge tekrar anavatana katılmıştır.

Bugün Armutlu Mahallesi ile Elmalı köyü arasındaki su kanalının yukarısından geçen ve hâlen kalıntıları var olan patika yola halk arasında Asker Yolu denmesi ve Elmalı köyünde Asker / Şehit Mezarları olarak bilinip kutsal kabul edilen mezarların olması ilçenin tarihsel geçmişinin halk üzerindeki etkisini göstermektedir. Gürcistan sınırında yer alan Arsiyan yaylasından geçen ve halk arasında Top Yolu olarak bilinen güzergâh da ilçenin ne kadar önemli bir coğrafyada bulunduğunun ve çeşitli kültürlere ve devletlere ev sahipliği yaptığının kanıtı niteliğindedir. Çalışmamızın hacminin artmaması ve üzerinde durmaya çalıştı̆̆ımız konu gereği tarihsel sürece yüzeysel olarak değindiğimizi hatırlatmak isteriz.

\section{Gelişme}

Kültürün hayvan adları üzerinde önemli etkileri olduğu açıktır. Kültürdeki gelişmeler diğer alanlarda olduğu gibi dilde kullanılan kelimeleri de etkilemektedir ve etkilemeye devam edecektir. Özellikle tarihî süreç içerisinde karşılaşılan din ve coğrafya değişiklikleri, farklı kültürlerle girilen iletişim, dili önemli oranda etkilemiş ve bu durum hayvan adlarında da kendini göstermiştir.

İlk yazılı belgelerimiz olan Göktürk Yazıtları Türk dili ve kültürü açısından kilometre taşlarından biridir. Yazıtlar, hayvan sembolleri bakımından ayrıca önem taşımaktadır. Yazıtlardaki "kurttan süt emen çocuk tasviri, ejder tasviri" semboller, yine Yazıtlardan itibaren yazılı belgelerde gördüğümüz "at ve diğer hayvanların" adlandırılması için yapılan işaretlemeler ve semboller bu önemi daha da arttırmaktadır. Uygurlara ait metinlerde de hayvanlarla olan ilişki açıkça görülmektedir. Maniheist Uygurlara ait Irk Bitig adlı eserde 37 adet hayvan işaretlemesi tespiti yapılmıştır ( Aydoğanlar, 2012: s.27-28 ).

Türk dilinin kilometre taşlarından bir diğeri olan Kutadgu Bilig de hayvan adları açısından zengin bir içeriğe sahiptir. Kutadgu Bilig'de geçen hayvan adlarının toplam sayısının 395 olduğu belirtilmektedir. Bu 395 işaretleme 79 farklı hayvandan oluşturulmuştur (Bozkaplan,2007:s.1118). İslami Dönem eserlerimiz içerisinde Türk dilinin söz varlığı ve hayvan adları bakımından en önemlilerinden biri de Divânü Lûgâtitt-Türk'tür. Divanda, Siçgan-Siçan / Fare, tavışgan - tavşan, porsmuk - porsuk gibi birçok hayvan adı bulunmaktadır ( Ercilasun, Akkoyunlu, 2015: s.174 / 149, 50/ 35 ).

Hayvan adları konusunda dile getirilmesi gereken unsurlardan biri de On İki Hayvanl Türk Takvimi'dir. Astronomi bilimiyle yakından ilgili olan On İki Hayvanlı Türk Takvimi’nin kökeniyle ilgili birçok açıklama yapılmıştır. Bu açıklamalar arasında belki de en önemlisini Kaşgarlı Mahmud, Divânü Lûgâtitt-Türk adlı eserinde yapmıştır. Türklerin on iki farklı hayvan adını yıllara vererek on iki yıllık bir takvim oluşturduğunu; çocukların yaşlarını, savaş tarihlerini ve diğer olayları bu şekilde tarihlendirdiğini belirten Kaşgarlı Mahmud, bu takvimin ortaya çıkışını da detaylıca açılamıştır (Akalın, 2008:s.110). Çok uzun yıllardır varlığını sürdürmesi, geniş bir coğrafi alana yayılıp kullanım alanı bulmasının yanında On İki Hayvanlı Türk Takvimi, insanlarla hayvanlar arasındaki ilişkiyi özellikle kültürel anlamda göstermesi bakımından önemlidir.

Yöre halkıyla kurduğumuz iletişim sonucunda elde ettiğimiz en önemli verilerden biri halkın bir kısmının kendilerini Ahıska Türkü olarak tanımlamasıdır. Bir kısmı ise biz Kıpçak Türküyüz veya Kuman Kıpçağız şeklinde tanımlamaktadır. Ellerinde herhangi bir yazılı belge olmadan bu şekilde tanımlama yapabilmelerini sözlü kültürün getirisi olarak düşünmekteyiz. Ahıska, Türkiye'nin kuzeydoğusunda bugün Gürcistan topraklarında yer alan çok eski bir Türklük yurdu merkezidir. Ahıska, 
Dede Korkut Kitabı'nda “Ak-Sika / Ak-Kale; 481 yılında Akesga adıyla anılan Eski Oğuzlar beldesidir ve 2700 yıllık bir Türk yurdudur” şeklinde geçmektedir ( Kırzıoğlu,1966:s.43 ). Kıpçaklar, kendilerinden önce Doğu Karadeniz’e göç eden kavimleri de bünyelerine alarak Batı Türkçesinin merkez kanadını teşkil etmişlerdir. Doğu Karadeniz bölümünde sadece Oğuz - Kıpçak değil aynı zamanda Peçenek, Bulgar vb. Türk boylarının da varlığı özellikle dil bilimciler ve toponomi ( yer adı bilimi ) düşünürleri tarafından tespit edilmiştir ( Özmenli,2016:s.515 ). Üzerinde çalıştığımız ilçedeki hayvan adları ve adlandırma da işte bu ve bunun gibi tarihsel, kültürel etkileşim ve gelişimin dil üzerindeki etkisini gösteren en önemli kanttlardan biridir.

\subsection{Yöntem}

Hayvan adlarını belirlerken Şavşat ilçesinde yöre halkı tarafından en çok bilinen ve görülebilenler seçilmiş olup liste halinde hazırlanan hayvan adları kaynak kişilere ayrı ayrı sorulmuştur. Öncelikle yakın çevremizden başlanarak hayvan adlarının karşılıkları yazılı ve sözlü olarak tespit edilmeye çalışılmıştır. Çalışmamızın niteliği açısından tek bir köy, tek bir aile seçilmemiş, farklı köylerde yaşamış, yaşamını orada devam ettiren ve farklı yaş gruplarından kişilerle hayvan adlarıyla ilgili konuşmalar yapılmıştır. Ağız özelliklerinin doğru tespiti için meslek hayatı boyunca bölgeden ayrılmamış, hâlen aynı bölgede yaşayan ve belirli yaş grubunun üzerindekilerin kaynak kişi olarak seçilmesine özen gösterilmiştir. Doğup büyüdüğümüz topraklar olması nedeniyle adlandırmalardaki seslere aşina olsak da yıllar önce bölgeden ayrılmanın vermiş olduğu dilsel değişimler bizleri, sesleri belirleme noktasında zorlamıştır. Kültürün dili etkilediği gerçeği kaynak kişilerde de kendisini göstermiş ve beraberinde farklı adlandırmaları ortaya çıkarmıştır. Öyle ki aynı yerleşim yerinde yaşayanlarda bile aynı hayvan için farklı adlandırmalar ve sesler tespit edilmiştir. S. Uyğur kişi adları ile ilgili yapmış olduğu çalışmasında farklı kullanımları; köyden şehre gidip uzun zaman şehrin tesirinde kalmış kişilerin doğup büyüdükleri yerleşim yerlerine döndüklerinde adlandırmaları ölçünlü Türkçe ile söylemeleri farklı kullanımları ortaya çlkartmıştır şeklinde açıklamıştır ( Uyğur,2013:s.67 ). Ağız araştırmalarında derlenen dil malzemesinin çözümlenmesi ve metin oluşturma işi bu çalışmaların en zor ve zahmetli işidir. Metinler çalışmanın esasını oluşturacağından, seslerin sağlıklı olarak tespiti ve yazıya aktarılması çok önemlidir ( Demiray, 2011:s.9 ). Bu yüzden aynı kelime birden çok defa kaynak kişilere tekrar ettirilmiştir ve sesler tespit edilmeye çalışılmıştır. Ancak farklı bir araştırmacının aynı dil malzemesinden farklı sesler algılayabilme ihtimali açıktır. Bu noktada alanında uzman araştırmacılarla yapılacak ortak çalışmaların, gerekli araç gereçlerin zorunluluğunu ve ses laboratuvarlarının önemini gündeme getirmenin yerinde olacağını düşünmekteyiz. Hayvan adlarında görülen dil bilgisel özellikleri belirlemede daha önce bölge veya Türkiye Türkçesi ağızları konusunda yapılan çalışmalardaki ölçütler örnek alınmış ve gerekli eklemelerle sınıflandırma genişletilmiştir.

\section{2. Şavşat ağzında kullanılan karşılıklar}

Ağaçkakan - ḳodova / ḳodava

Ağustos Böceği - cır cır bócúgi / çiçina bócúgi / çisnatela

Akbaba - akbaba / zera

Akrep - akrab

Arı - petek / ḅıiziki

At - küheylan / beygir

Aygir - aygir

Ayı - avi / datvi / mosso / mosso ag̉a / ḅalaği (Yavru ayılara verilen ad) 
Balık - ḅalug / ḅaluk

Baykuş - buḳuşi / geca ḳuşi / ćo ḳuşi

Bıldırcın - bıldırçin / çıvıki

Bit - ḳırni / boço

Boğa - buga / țosun

Boru (Büyük Sinek) - bori

Buzağ - țana

Bülbül - búlbúl

Camış - camuş / manda / ķotiḱ (Yavru manda) / gedek (Bir yaşında olanlara verilen ad) / şişek (Yavrulama zamanı gelenlere verilen ad)

Ceylan - ceylan

Civciv - çuçul / çuçuli / ferik (Yaşça biraz daha büyümüşs olanlara verilen ad)

Çakal - çaḳal

Çekirge - çaḳurga

Çıyan - çiyan / çiyanni

Dağ Keçisi - țag keçisi / yabani keçi

Doğan - ḳordoġan

Domuz - doñguz / țoñguz / hınzır

Enik - enúk / bitik

Eşek - merkep

Eşek Arısı - ḅızīki / ḅırịhi (Beli sarı olup tombul olanlara verilen ad)

Fare - siçan

Geyik - geyuk

Güvercin - gogarçin / hopal / kedana (Büyük kelebeklere verilen ad)

Horoz - horoz

İbibik - ibibik

Karga (Saksağan) - ḳarg̉a / ḳuzgun (Gri renkte olanlara verilen ad) / kaçķaça (Alacamsı renkte olanlara verilen ad) / Ardahan ḳargasi (Simsiyah renkte olanlara verilen ad)

Karınca - ḳarunca / avi ḳarīncasi (Büyük olanlara verilen ad)

Kartal - atmaca / zera

Katır - katır

Kaz - kaz

Keçi - çepiç (oğlak) / kૂeçi / ḳıdan / țitan (Yeni doğmuş keçiye verilen ad) / ḳorut (teke)

Kedi - pisik / çințal (kedi yavrusu)

Keklik - keklúğ / yaban țavugi

Kelebek (Büyük Kelebek) - ḅeḅela / güve (Un içerisinde yaşayanlara verilen ad)

Kene - kֵırni / gena / ḳord genasi (Kırmızımsı olup herhangi bir yere yapışmamışsa verilen ad) / țigīrbi (Herhangi bir hayvana yapışmış ve şişmişse verilen ad)

Kertenkele - veşvela (Yeşil renkli olanlara ve küçük olanlara verilen ad) / hulúkii

Kırlangıç - yaġmur ḳuşi

Kısrak - kıırag 


\section{Kirpi - kipri / zì̈grbi}

Koç - ḳuzi / țoḳli (Bir yaşında olanlara verilen ad)

Koyun - țavar (Boynuzsuz olanlara verilen ad) /şişek (Yavrulama zamanı gelen koyunlara verilen ad) / kale (Boynuzsuz dişi koyunlara verilen ad) / țoḳli (Bir yaşını geçmiş koyunlara verilen ad)

Köpek - it / ḳuțuz / qúda (Kuyruğu kopmuş veya kesilmiş olanlara verilen ad)

Köstebek - köstebek

Kulak Böceği - kulak bócúgi

Kurbağa - bakakại / gabel (Büyük kurbağalara verilen ad)

Kurt - kurd

Kuş - ḳuş

Kuzu - ḳuzi (Yeni doğmuş koyun)

Leylek - leylek

Mal (İnek başta olmak üzere büyükbaş hayvanların tümüne verilen ad) - țana (Büyükbaş hayvanların yavrusu) / yoz - moziḱ (Biraz büyümüş olanlara verilen ad) / dügá (Yavrulama zamanı gelmiş olanlara verilen ad) / kolik (Büyükbaş hayvanların boynuzları kırık olanlara verilen ad)

Manda Yavrusu - gedek / kotik

Öküz - oqúz / dole (Boynuzları kırılmış olanlara verilen ad)

Örümcek - boçoccúva (Hem örümceğe hem de yuvasına verilen ad)

Pire - pira / ḳrni

Porsuk - posruk

Saksağan - kaç̧kaça

Sansar - sansar / senser

Serçe - serçe

Siçan - siçan

Sığır - siğır / inek

Sincap - teyin / tatarzána / kַevi / ğivi (Küçük boyutlu olanlara verilen ad)

Sinek - sinek

Sivrisinek - mumli

Solucan - çiyakela

Sümüklü Böcek - loḳora

Şahin - zera

Tahtakurusu - boțoṭ / tahta ḳurdi / çiyanni (Meyvelerden özellikle eriklerin içinde yaşayanlara verilen ad) / tahta bịịi

Taraklı Kuş - ḳuḳku ḳuşi

Tavşan - țavşan

Tavuk - țavuğ / tavuh

Tay - kúriḱ

Teke - teke

Tirtıl - tırtıl / boṭot

Tilki - tilki / hozan tilkisi (Zayıf olanlara verilen ad)

Turna - țurna 
Uğur Böceği - meriya / meriyın

Yavru köpek - bịitig

Yılan - bócúk (Yllan ve benzeri sürüngenlerin tamamına verilen ad)

\section{Hayvan adlarında görülen özellikler}

\section{1. Ünlüler}

á ünlüsü: "a" ile "e" arasında bir orta damak ünlüsüdür. Normal "a" ünlüsünden daha ince ve daha kısadır. e > a yönündeki değişmenin ve "k, g, l” ünsüzlerinin yumuşatıcı etkisiyle oluşan bir ara sestir. Ancak bu kuralın dışında da sözcükler vardır.

Mal (İnek başta olmak üzere büyükbaş hayvanların tümüne verilen ad ) - dügá (Yavrulama zamanı gelmiş olanlara verilen ad)

Sincap - tatarzána

i ünlüsü: "ı" ile "i” arasında bir ünlüdür. Şavşat ağzında ön ve son seslerde " 1 " ünlüsü yok denecek kadar az görülmektedir. Bunu sebebi olarak diğer Doğu Grubu ağızlarında olduğu gibi Şavşat ağzının da "ı" ünlüsünü pek sevmediği gösterilebilir. Bundan dolayıdır ki yazı dilinde çok görülmese de özellikle konuşma dilinde son hecede bulunan "ı" ile "i" arasında bir ünlü olan "ī"nın kullanımı çok azdır.

Arı - ḅızīki

Eşek Arısı - ḅızî̉ki / ḅıriḥi (Beli sarı olup tombul olanlara verilen ad)

Karınca - avi ḳarincasi (Büyük olanlara verilen ad)

Kene - ț̣igirbi (Herhangi bir hayvana yapışmış ve şişmişse verilen ad)

Kirpi - zíg̈arbi

ó ünlüsü: “o” ile "ö” arasında bir ünlüdür. o > ö yönündeki değişimin ve "k, g, l” ünsüzlerinin yumuşatıcı etkisiyle oluşan bir ara sestir.

Ağustos Böceği - cır cır bócúgi / çiçina bócúgi

Kulak Böceği - ḳulak bócúgi

Yılan - bócüḱk (Yllan ve benzeri sürüngenlerin tamamına verilen ad)

ú ünlüsü: "u” ile “ü" arasında bir ünlüdür. " $\mathrm{g}, \mathrm{k}$, ğ" seslerinin kalınlaştırıcı etkisiyle ortaya çıkar.

Ağustos Böceği - cır cır bócúgi / çiçina bócúgi

Bülbül - búlbúl

Enik - enúk

Geyik - geyúk

Keklik - keklúg

Köpek - qúda (Kuyruğu kopmuş veya kesilmiş olanlara verilen ad)

Kulak Böceği - kulak bócúgi

Öküz - oqúz

Örümcek - boçoccúva (Hem örümceğe hem de yuvasına verilen ad)

Tay - kúrik 
Yılan - bócúḱ (Yllan ve benzeri sürüngenlerin tamamına verilen ad)

ù ünlüsü: “o”ya yönelik yarı kapalı “u” ünlüsüdür. Nadir olarak görülen ünlülerden bir tanesidir.

Doğan - ḳordùgan

\subsection{1. Ünlü uyumları}

Büyük ünlü uyumu (kalınlık-incelik uyumu), Türkçenin temel niteliklerinden biridir. Sadece Batı Türkçesinde değil Ural - Altay diyalektlerinde de ileri bir seviyededir. Artvin ili Şavşat ilçesinde bu uyum eklerin tek şekilli olması, ünlü değişimleri, ünlü benzeşmeleri, kelime sonundaki dar ünlülerin “i”ye dönüşmesi ve aynı sesin kelime köklerinde kendine yer bulması gibi nedenlerle pek de sağlam değildir. A. Bican Ercilasun'un deyimiyle kelimeler âdeta ünlü uyumlarına isyan halindedir. Ancak Türkiye Türkçesi yazı dilinde uyum dışında kalan birçok Türkçe sözcüğün Şavşat ağzında eski biçimleriyle korunmakta olup uyuma uyduğu ve bugün uyum dışı kalan alıntı sözcüklerin kalınlıkincelik uyumuna uyduğu görülmektedir (ana, alma, kirez, emeliyat... vb.).

Ağustos Böceği - crr cır bócúgi / çiçina bócúgi / çisnatela

Arı - ḅıziki

At - küheylan

Ayı - avi / datvi / ḅalaği (Yavru ayllara verilen ad)

Baykuş - buḳuşi / geca ḳuşi / ćo ḳuşi

Bıldırcın - bıldırçin / çıvıki

Bit - kırni

Boru (Büyük Sinek) - bori

Camış - ḳotiḱ (Yavru manda)

Ceylan - ceylan

Civciv - çuçuli

Çıan - çiyan / çiyanni

Enik - enúk / bitik

Eşek Arısı - ḅızikni / ḅırị̣i (Beli sarı olup tombul olanlara verilen ad)

Fare - siçan

Güvercin - gogarçin / kedana (Büyük kelebeklere verilen ad)

Karınca - ḳarunca / avi ḳarīncasi (Büyük olanlara verilen ad)

Kartal - zera

Keçi - țitan (Yeni doğmuş keçiye verilen ad)

Kedi - çințal ( kedi yavrusu )

Keklik - keklúğ / yaban țavugii

Kelebek (Büyük Kelebek) - ḅeḅela

Kene - kıırni / gena / ḳord genasi (Kırmızımsı olup herhangi bir yere yapışmamışsa verilen ad)/ țịïrbi (Herhangi bir hayvana yapışmış ve şişmişse verilen ad)

Kertenkele - veşvela (Yeşil renkli olanlara ve küçük olanlara verilen ad) / hulúḱi

Kirpi - kipri / zì̈arbi

Koç - ḳuzi / țoḳli ( Bir yaşında olanlara verilen ad ) 
Kulak Böceği - kulak bócúgi

Kurbağa - baḳaḳi / gabel (Büyük kurbağalara verilen ad)

Kuzu - kuzuzi (Yeni doğmuş koyun)

Mal - moziḱ (Biraz büyümüş olanlara verilen ad) / dügá (Yavrulama zamanı gelmiş olanlara verilen ad) / kolik (Büyükbaş hayvanların boynuzları kırık olanlara verilen ad)

Pire - pira / ḳrni

Siçan - siçan

Sincap - teyin / tatarzána

Sivrisinek - mumli

Solucan - çiyakela

Şahin - zera

Küçük ünlü uyumu (düzlük-yuvarlaklık uyumu), Batı Türkçesinde düzleşme yönünde görülmektedir. Düz ünlülerden (a, e, l, i) sonra düz, yuvarlak ünlülerden (o, ö, u, ü) sonra yuvarlak dar $(\mathrm{u}, \ddot{u})$ veya düz geniş $(\mathrm{a}, \mathrm{e})$ ünlülerin gelmesi kuralına dayanan uyum, Eski Anadolu Türkçesinde görülen yuvarlaklaşma eğiliminden dolayı bozuktur.

Ağaçkakan - kodova

Ağustos Böceği - cır cır bócúgi / çiçina bócúgi / çísnatela

Ayı - mosso / mosso aǵa

Balık - ḅalug / ḅaluk

Bit - boço

Boru (Büyük Sinek) - bori

Camıș - camuş / kotiḱ (Yavru manda)

Civciv - çuçuli

Çekirge - çakururga

Doğan - kordoġan

Enik - enúk / bitik

Geyik - geyuk

Horoz - horoz

Karınca - karunca

Keklik - keklúg / yaban țavug̈i

Kırlangıç - yaġmur ḳuşi

Koç - ḳuzi / țoḳli (Bir yaşında olanlara verilen ad)

Koyun - țokli (Bir yaşını geçmiş koyunlara verilen ad)

Kulak Böceği - kulak bócúġi

Kuzu - kuzi (Yeni doğmuş koyun)

Mal - mozik (Biraz büyümüş olanlara verilen ad) / ḳolik (Büyükbaş hayvanların boynuzları kırık olanlara verilen ad )

Örümcek - boçoccúva (Hem örümceğe hem de yuvasına verilen ad)

Sivrisinek - mumli

Sümüklü Böcek - loḳora 
Tahtakurusu - boṭoț / tahta ḳurdi

Tavuk - țavuğ / tavuh

Tay - kúriḱ

Tirtıl - boțoț

\subsection{2. Ünlülerle ilgili ses olayları}

Çok heceli kelimelerin başındaki veya sonundaki “1, $u$, ü" ünlülülerinin "i” ile temsil edilmesi: Kuzey Doğu Grubu ağızları içerisinde yer alan Şavşat ağzında "i”leşme çok yaygındır. “i”leşme ünlü uyumunu alt üst etmesinin yanında üzerine ek aldığında dahi çoğu zaman değişmez. Bu özellik Kuzey Doğu Grubu ağızları için karakteristiktir. Aynı zamanda 3. tekil şahıs iyelik eki “-i” , yükleme hâli eki “-i”, soru eki "mi”, bilinen ( görülen ) geçmiş zaman eki “-di” sadece düz, dar, ince ünlülü şeklinde görülmektedir.

Ayı - avi

Baykuş - buḳuşi / geca ḳuşi / ćo ḳuşi

Bıldırcın - bıldırçin / çıvıki

Boru ( Büyük Sinek ) - bori

Çıyan - çiyan / çiyanni

Fare - siçan

Karga (Saksağan) - Ardahan ḳargaasi (Simsiyah renkte olanlara verilen ad)

Karınca - avi ḳarīncasi (Büyük olanlara verilen ad)

Keklik - yaban țavugi

Kırlangıç - yag̉mur ḳuşi

Koç - kuzi

Kuzu - ḳuzi (Yeni doğmuş koyun)

Sivrisinek - mumli

Tahtakurusu - tahta ḳurdi

Taraklı Kuş - ḳuḳḳu ḳuşi

Kök ve ek ünlüsünde meydana gelen kalınlaşmalar: Anadolu ağızları için ayırıcı bir nitelik arz eden ünlü kalınlaşması, ek ünlüsünden kök ünlüsüne kadar uzanan ve belirli bir faktöre bağlanmadan o bölgenin yaygın bir eğilimi olarak karşımıza çıkan kalınlaşmalardır (Karahan, 2011; s.8).

Baykuş - geca ḳuşi / ćo ḳuşi

Çekirge - çaḳurga

Enik - enúk

Geyik - geyuk

Güvercin - gogarçin

Keklik - keklúg

Kene - gena / kord genasi

Kertenkele - veşvela (Yeşil renkli olanlara ve küçük olanlara verilen ad)

Kulak Böceği - kulak bócúgi 
Mal - dügá (Yavrulama zamanı gelmiş olanlara verilen ad ) /

Öküz - oqúz / dole (Boynuzları kırılmış olanlara verilen ad )

Pire - pira

Kök ve ek ünlüsünde meydana gelen incelmeler: Kuzeydoğu Grubu ağızlarının incelme yönünde eğilim göstermesi ve diş ünsüzlerinin (/d/, /t/, /c/, /ç/, /j/, /ş/, /z/,/s/, /n/, /l/, /r/) etkisiyle birlikte meydan gelen incelmeler bu grubu diğer ă̆ız özelliklerinden ayırmaktadır.

Ayı - avi

Baykuş - geca ḳuşi / ćo ḳuşi

Bıldırcın - bıldırçin / çıvıki

Boru (Büyük Sinek) - bori

Çıyan - çiyan / çiyanni

Fare - siçan

Karınca - avi karīincasi (Büyük olanlara verilen ad)

Kırlangıç - yağmur ḳuşi

Koç - ḳuzi / țoḳli (Bir yaşında olanlara verilen ad)

Koyun - țoḳli (Bir yaşını geçmiş koyunlara verilen ad)

Pire - kırni

Siçan - siçan

Sivrisinek - mumli

Taraklı Kuş - ḳuḳḳu ḳuşi

Kök ve ek ünlüsünde meydana gelen yuvarlaklaşmalar: Bir kısmı Eski Anadolu Türkçesi ile bağlantılı olan ünlü yuvarlaklaşmalarında, dudak ve diş dudak ünsüzleri (/m/, /b/,/p/, /v/,/f/) de rol oynar. Ayrıca kelime içindeki herhangi bir yuvarlak ünlü, komşu ünlüleri yuvarlaklaşma yönünde etkileyebilmektedir. $\mathrm{Bu}$ değişme, Anadolu ağızlarındaki Kıpçak Türkçesi izlerinden birisidir (Karahan,2011;s.17). Şavşat ağzında düzenli şekilde görülen yuvarlaklaşma düzlük - yuvarlaklık uyumsuzluğunun da başlıca nedenidir. Ağustos Böceği - cır cır bócúgì / çiçina bócúġi

Balık - ḅalug / ḅaluḳ

Camış - camuş

Çekirge - çaḳurga

Enik - enúk

Geyik - geyuk

Karınca - ḳarunca / avi ḳaríncasi (Büyük olanlara verilen ad)

Keklik - keklúg / yaban țavugi

Kulak Böceği - ḳulak bócúgi

Yılan - bócúḱ (Yılan ve benzeri sürüngenlerin tamamına verilen ad)

Kök ve ek ünlüsünde meydana gelen düzleşmeler: İlk hecede bulunan yuvarlak ünlülerin (o, ö, u, ü) düz ünlülere (a, e, l, i) dönüşmesi Kuzeydoğu Grubu ağızları için karakteristik özelliklerden birisidir. Ancak üzerinde çalıştığımız Şavşat ilçesindeki hayvan adları ve adlandırmalarda ilk hece 
dışında da " $u$, ü” ünlülülerinin "i” ile temsil edilmesinden kaynaklanan düzleşmeler yoğun olarak görülmektedir. Baykuş - buḳuşi / geca ḳuşi / ćo ḳuşi

Boru (Büyük Sinek) - bori

Kurlangıç - yag̉mur ḳuşi

Koç - ḳuzi / țoḳli (Bir yaşında olanlara verilen ad)

Koyun - țoḳli (Bir yaşını geçmiş koyunlara verilen ad)

Kuzu - kuzui (Yeni doğmuş koyun)

Sivrisinek - mumli

Taraklı Kuş - kukụku ḳuşi

\section{2. Ünsüzler}

Arka damak ünsüzü " $\dot{g}$ ”nin iki ünlü arasında korunması: " $k$ > g g" değişimi iki ünlü arasında ve hece sonlarında korunur ve bu ağız özelliğinde yoğun olarak görülür. Bu değişim bakımından Şavşat ağzı, Batı Grubu ağızları ile yakınlaşır. “ḳıra’g” örneğinde son ses olarak kendisini korumuştur.Ağustos Böceği - cır cır bócúgi / çiçina bócúgi

Ayı - ḅalagii (Yavru ayılara verilen ad)

Boğa - buğa

Doğan - ḳordoġan

Keklik - yaban țavugi

Kene - țigïirbi (Herhangi bir hayvana yapışmış ve şişmişse verilen ad)

Kısrak - kıısrag

Kirpi - zig̀arbi

Kulak Böceği - kulak bócúgi

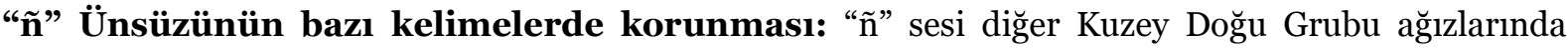
olduğu gibi Şavşat ağzında da kişisel söylemler dışında "n” ye dönüşmüştür. "yüñ, añla-, öñle (öğlen vakti), yoña... vb. gibi birkaç sözcükte şahsi konuşma özellikleriyle "ñ" sesi korunmaktadır. Ön ve arka boğumlanmalı olarak iki şekilde görülen " $\tilde{n}$ " sesi çalışmasını yaptığımız hayvan adlarında tek bir örnekte görülmektedir.

Domuz - doñg்uz / țoñguz

"hn” ünsüzü sadece ön ve iç seste bulunması: Hırıltıll, sızıcı ve arka damak ünsüzü olan "h" Kuzeydoğu Grubu ağızlarının ayırt edici ve belirleyici başlıca özelliklerinden birisidir. “-k > -ḩ” değişimi Eski Türkçe döneminden sonra ortaya çıkmış, Eski Anadolu Türkçesinde de kelime içi ve sonunda birçok sözcükte görülmüştür. Şavşat ağzında da çok sık görülen ses değişimlerinden birisidir. Yaptı̆̆ımız çalışmada sadece “tavuh" örneğinde son seste istisnai olarak görülmektedir.

Ancak daha kapsamlı bir derleme çalışmasıyla "ḩ" ünsüzü ile ilgili farklı kullanımların ortaya çlkabileceği görüşündeyiz.

Kertenkele - hulúki

Tavuk - tavuh 


\subsection{1. Ünsüzlerle ilgili ses olayları}

Ünsüz ikizleşmesi: Aynı ünsüzün bir sözcükte yan yana gelmesiyle oluşan ses olayıdır. Bölgede çok sık görülmemektedir.

Ayı - mosso / mosso aġa

Örümcek - boçoccúva (Hem örümceğe hem de yuvasına verilen ad)

Taraklı Kuş - ḳuḳḳu ḳuşi

Yer değiştirme (Göçüşme): Şavşat ağzında göçüşme, Türkiye Türkçesinde olduğu gibi çoğunlukla söyleyişi kolaylaştırmak için yapılır ve umumiyetle boğumlanması zayıf " $r$ " ünsüzünden kaynaklanmaktadır.

Kirpi - kipri

Porsuk - posruk

\section{Sonuç}

Giriş bölümünde etnik ve kültürel yapısını özetleyip Gelişme bölümünde hayvan adları ve özelliklerini vermeye çalışılan Şavşat ağzının Eski Anadolu Türkçesi ve Kıpçak Türkçesiyle yakından ilgili olduğu görülmektedir (düzleşmeler, yuvarlaklaşmalar... vb.). Şavşat ağzında, 86 farklı hayvan türünün 155 farklı sözcükle adlandırıldığı ve bu adlandırmaları yaparken yöre halkının belli başlı ölçütleri kullandığı tespit edilmiştir. Bunlardan en önemlisi kültürel etkileşime girdikleri toplumlarda var olan adları değiştirmeden kullanmalarıdır. "Ayı” sözcüğünün Gürcüce karşılığı "Datvi”dir. Sınır komşusu olduğu için Şavşat ilçesine bağlı köylerde de bu kullanımın varlı̆̆ı kaçınılmaz olmuştur. Öyle ki ilçeye bağlı köylerde kullanılan birçok yer ve kişi adı da Gürcü kökenlidir. Adlandırmalarda kullanılan diğer ölçütler ise hayvanların boyutları, renkleri, yaşları, yaşadığı alanları ve yakın türde olanlara aynı adları verilmesidir:

Hayvanların boyutları (kedana - Büyük kelebeklere verilen ad / gabel - Büyük kurbağalara verilen ad),

Renkleri (Ardahan ḳargaasi - Simsiyah renkte olan kargalara verilen ad / veşvela - Yeşil renkli olanlara ve kü̧̈ük boyutlu olan kertenkelelere verilen ad),

Yaşları (dügá - Yavrulama zamanı gelmiş olan büyükbaş hayvanlara verilen ad / țoḳli - Bir yaşında olan koçlara verilen ad),

Yaşadığı alanlar (güve - Un içerisinde yaşayan kelebeklere verilen ad / çiyanni - Meyvelerden özellikle eriklerin içine yaşayan tahtakurusuna verilen ad),

Yakın türdeki hayvanlarda aynı adın kullanıldığı tespit edilmiş̧ir [ Koç - ḳuzi / țoḳli (Bir yaşında olanlara verilen ad) / Koyun - țoḳli (Bir yaşını geçmiş koyunlara verilen ad / Kuzu-ḳuzi (Yeni doğmuş koyun) ].

Bu ölçütler dışında hayvan adları temel alınarak Şavşat ağzıyla ilgili şunlar söylenebilir:

1. Ünlü kalınlaşması ile ortaya çıkan kalınlık - incelik uyumsuzluğu yoğun olarak görülmektedir. 
2. “ñ” ünsüzü birkaç örnek ve bireysel söylemler dışında Türkiye Türkçesinde olduğu gibi "n” ye dönüşmüştür.

3. "hn" ünsüzü genelde ön ve iç seste bulunma eğiliminde olup bir örnekte son ses olarak kullanıldığı görülmektedir.

4. Çok heceli kelimelerin başındaki veya sonundaki “l, u, ü” ünlüleri “i” ile temsil edilmiştir. Ünlü uyumsuzluğunun başlıca nedenlerinden olan “i”leşme Şavşat ağzında yoğun olarak görülmektedir.

5. Şavşat ağzında Türkiye Türkçesinde olmayan “á, ì, ó, ú, ù” ara ünlüleri bulunmaktadır.

6. Şavşat ağzında Türkiye Türkçesinde var olan ünsüzlerden farklı olarak çeşitli ünsüzler bulunmaktadır: k, g̀, ç, k, ḅ, ć, ḱ, ñ, ḥ, ho, ț, ğ, q

7. $\mathrm{c}>\mathrm{c}, \mathrm{a}>\mathrm{e}, \mathrm{e}>\mathrm{a}, \mathrm{o}>\mathrm{u}, \mathrm{y}>\mathrm{v}, \mathrm{l} / \mathrm{i}>\mathrm{u}, \mathrm{t}>\mathrm{d}, \mathrm{k}>\mathrm{g}$ hayvan adlarında görülen belli başlı ses değişikliklerdir. Bunun sonucu olarak da düzleşme, yuvarlaklaşma, incelme, kalınlaşma gibi ses olayları yoğun olarak görülmektedir.

\section{Kaynak Kişiler}

Ahmet YAZICI - Çiftçi - Yaşar Köyü ( țabagetil )

Ali Naci YILDIZ - Kütüphane Memuru - Şalcı Köyü (çuvareḅ)

Asim ALTUNTAŞ - Öğretmen - Yaşar Köyü ( țabagetil )

Atanur OCAKLI - Emekli Emniyet Memuru- Kayadibi Köyü (sıhızır)

Dursun ÖZDEDE - Öğretmen - Atalar Köyü (çisveț)

Enis TEK - Emekli Öğretmen - Çavdarlı Köyü (ḉorsel)

Fahrettin BALCI - Öğretmen - Ilıca Köyü (cinal)

Faruk ALBAY - Ziraat Teknisyeni - Kireçli Köyü (ḱötátris)

Hasan ALTUNTAŞ - Öğretmen - Yaşar Köyü ( țabagetil )

İmsak KILIÇ - Emekli Memur - Şalcı Köyü (çuvareb)

Salih TEMİ - Emekli Memur - Saylıca Köyü (ḳaravaț)

Yalçın TEMIZ - Emekli Öğretmen - Tepeköy (ahaldaba)

Yüksel KIZILALTUN - Emekli Memur - Tepeköy (ahaldaba)

Zeki KÖR - Emekli Memur - Ilıca Köyü (cinal)

\section{Kaynakça}

Akalın, Şükrü Halûk (2008). Bin Yıl Önce Bin Yıl Sonra Kâşgarlı Mahmud ve Divanü Lugati’t -Türk. Ankara: TDK: 110.

Akca, Hakan ( 2017 ). Ağız Çalışmalarında Derleme Konuları ve Kaynak Kişileri Yöneltilecek Sorular. Hacettepe Üniversitesi Türkiyat Araştırmaları Dergisi, 2017 Güz (27), 61-84.

Arısoy İbrahim; Golden, Prof. Dr. Peter; Gözaydın, Prof. Dr. Nevzat (İnc.) (2010). Gürcüce- Türkçe Sözlük. Ankara: TDK.

Aydın, Erhan (2018). Orhun Yazıtları. İstanbul: Bilge Kültür Sanat

Aydoğanlar, Erman (2012). Irk Bitig' de Hayvan Adları ve Hayvanlarla İlişkili Kavramlar. IJSES Uluslararası Sosyal ve Ekonomik Bilimler Dergisi. 2 ( 1 ), s. 27-30. 
Boz, Erdoğan ve Aktaş, Semra Günay (2017). Eskişehir Dil Atlası. Ankara: Gazi Kitabevi.

Bozkaplan, Şerif Ali (2007). Kutadgu Bilig'deki Hayvan Adları Üzerine Bir İnceleme. Turkish Studies, 2 (4), 1110-1118.

Bulut, Serdar (2017). Asya Studies - Ahıska Bölgesi Türkleri Ağzından Derleme Sözlüğüne Katkılar- I. Academic Social Studies/Akademik Sosyal Araştırmalar Number: 2, p. 9-16, Winter 2017.

Bulut, S. (2013). Türkiye Türkçesi Ağızları Üzerine Çalışma Yapılmayan İl ve İlçeler. Turkish StudiesInternational Periodical For The Languages, Literature and History of Turkish or Turkic, Volume:8/1, Winter, p.1129-1149.

Buran, Ahmet (2009). Doğu ve Güneydoğu Anadolu'nun Dil Atlası. İstanbul: Biyografi.net.

Caferoğlu, Ahmet (1994). Kuzeydoğu İllerimiz Ağızlarından Toplamalar, Ordu, Giresun, Trabzon, Rize ve Yöresi Ağızları. Ankara: TDK: 116.

Demir, N. (2012). Türkçe Ağız Araştırmalarında Bazı Yöntem Sorunları. Diyalektolog, 4, 1-8

Demiray, Erdinç (2011). Ahıska Türkleri Ağzı. (Basılmamış Doktora Tezi ).

Ercilasun, Ahmet Bican (1983). Kars İli Ağızları - Ses Bilgisi. Ankara: TDK.

Ercilasun, Ahmet Bican; Akkoyunlu Ziyat (2015). Dîvânu Lugâti’t-Türk: Giriş-Metin-Çeviri-NotlarDizin. Ankara: TDK.

Gemalmaz, E. (1995). Erzurum İli Ağızları ( İnceleme - Metinler - Sözlük ve Dizinler). Ankara: TDK.

Gülensoy, Tuncer (1988). Kütahya ve Yöresi Ağızları. Ankara: TDK.

Gülensoy, Tuncer; Alkaya, Ercan (2011). Türkiye Türkçesi Ağızları Bibliyografyası. Ankara: Akçağ Yayınları.

Günay, Turgut (2003). Rize İli Ağızları (İnceleme-Metinler-Sözlük). Ankara: TDK: 795.

Karahan, Leyla (2011). Anadolu Ağızlarının Sinıflandırılması. Ankara: TDK.

Karahan, Leyla (2012). Ağız Çalışmalarında Bilimsel Niteliğin Korunması Üzerine Birkaç Not. Turkish Studies, 7 (4), 131-136.

Kırzıoğlu, Fahrettin (1966). Ahıska Üzerine Halk Deyişlerimizden, Çıldır Ardahan Hanak Posof. Ankara.

Özkan, İbrahim Ethem (1994). Ardanuç ve Yöresi Ağızları. Kayseri (Yayımlanmamış Yüksek Lisans Tezi, Erciyes Üniversitesi).

Özmenli, Mehmet (2016). Ortaçağ’da Doğu Karadeniz'de Oğuz ve Kıpçak Yerleşimi. Atatürk Üniversitesi Sosyal Bilimler Enstitüsü Dergisi Nisan 201620 (2): 515-536.

Polat, Fadime (2000). Şavşat ve Yöresi Ağızları (Yayımlanmamış Yüksek Lisans Tezi, Erciyes Üniversitesi).

Arat, R. R. (1999). Kutadgu Bilig I. cilt: Metin. Ankara: TDK.

Arat, R. R. (1994). Kutadgu Bilig II. cilt: Çeviri. Ankara: TDK.

Arat, R. R. (1979). Kutadgu Bilig III. cilt: İndeks. Ankara: Türk Kültürünü Araştırma Enstitüsü.

Arat, R. R. (2006). Kutadgu Bilig, Metin-Tercüme-Dizin. İstanbul: Kabalcı.

Tekin, Talat (2018). Orhun Yazıtları. Ankara: Bilgesu Yayıncılık.

Tokdemir, Hayrettin (1993). Artvin Yöresi Folkloru. Ankara.

Turan, Zikri (2006). Artvin İli Yusufeli İlçesi Uşhum Köyü Ağzı. Ankara: TDK.

Türk Dil Kurumu (2011). Büyük Türkçe Sözlük. Ankara: TDK.

Türk Dil Kurumu (1999). Ağız Araştırmaları Bilgi Şöleni. Ankara: TDK: 697.

Uçar, İlhan (2013). Türkiye Türkçesinde Hayvan Adlarında Türetilmiş Bitki Adları. Uluslararası Türkçe Edebiyat Kültür Eğitim Dergisi Sayı: 2/1 2013 s. 1-19. 
52 / RumeliDE Journal of Language and Literature Studies 2019.Ö6 (November)

An experiment on animal names used in Şavşat province of Artvin / A. F Altuntaş (pp. 37-52)

Uyğur, Sinan (2013). Artvin İlinin Sarıbudak Köyünde Kullanılan Kişi Adları ile Bunlarda Meydana Gelen Ses Değişimleri. Diyalektolog - Ulusal Hakemli sosyal Bilimler Dergisi Sayı 7, Sayfa:63-92. 